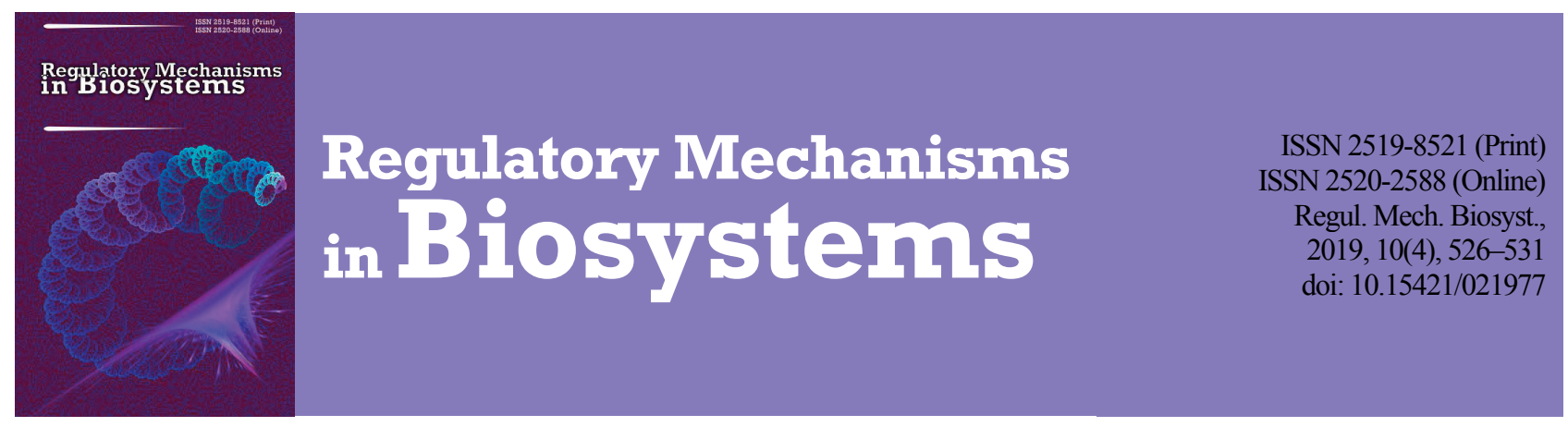

\title{
Heavy metals, nitrates and radionuclides in milk of cows depending on their stress resistance
}

\author{
O. M. Chernenko*, R. A. Sanzhara*, N. M. Shulzhenko*, R. V. Mylostyvyi*, O. V. Denisyk** \\ *Dnipro State Agrarian and Economic University, Dnipro, Ukraine \\ **State Institute of Grain Culture NAAS of Ukraine, Dnipro, Ukraine
}

Article info

Received 15.09.2019

Received in revised form 12.10.2019

Accepted 13.10.2019

Dnipro State Agrarian and Economic University S. Efremov st., 25 Dnipro, 49600, Ukraine. Tel.: + 38-067-528-97-62. E-mail: chernenko_an@ukr.net

State Institute of Grain Culture NAAS of Ukraine, V. Vernadskyst., 14 Dnipro, 49027, Ukrain E-mail:pectoral25@ukr.net
Chernenko, O. M., Sanzhara, R. A., Shulzhenko, N. M., Mylostyvyi, R. V., \& Denisyk, O. V. (2019). Heavy metals, nitrates and radionuclides in milk of cows depending on their stress resistance. Regulatory Mechanisms in Biosystems, $10(4), 526-531$. doi:10.15421/021977

The paper presents the results of studies on the content of cesium, strontium, zinc, cadmium, copper, lead and nitrates in the milk of Ukrainian black-and-white milk breed cows with different resistance to stress. The resistance of cows to stress was determined by concentration of cortisol in the blood one hour after a stress effect. The following factors were stressful: fixation of animals for one hour and pre-selection of blood by a veterinarian for general analysis. The objective of the research was establishing a connection between the different adaptive potential of Ukrainian black-and-white milk breeds and the ability of their bodies to excrete via the milk heavy metal salts, nitrates and radioactive elements which enter the body with food and water. The scientific hypothesis was that the state of pressure which occurs in the body under the influence of stress impairs homeostasis. It can affect the quantity and quality of products, it can cause disorders in the metabolic processes, the synthesis of milk components and introduction of some harmful substances into milk, which are differently accumulated in the body of cows with diverse reactions to stress and can be excreted with milk in at different levels. We established that different resistance of cows to stress can affect the concentration of the investigated harmful substances in milk. Concentration of lead, cadmium, zinc and nitrates was lower in milk of more stress-resistant cows (the first group). Their milk had a lower specific activity of ${ }^{137} \mathrm{Cs}$ and ${ }^{90} \mathrm{Sr}$. For all the seasons, the reliable results were obtained only for nitrates, and ${ }^{137} \mathrm{Cs}$ and ${ }^{90} \mathrm{Sr}$ - in spring, summer and autumn. Thus, milk of cows with higher resistance to stress is safer in terms of contents of the investigated elements. We have drawn a conclusion that stress can affect the ability of the body to excrete via the milk harmful elements which enter the body with food and water. Perspectives of further research are determining the effect of cows' stress resistance on the suitability of milk for the production of baby food products.

\section{Introduction}

Heavy metals are recognized as pathogenic pollutants of atmospheric air, water bodies and soils at global and regional scales (Kumar et al., 2019). This requires constant monitoring of their content and taking measures to neutralize these hazardous components (Sikdar \& Kundu, 2017). However, not all heavy metals are equally hazardous. Some of them are microelements necessary for the regular functioning of living organisms. However, when present in excess they have a negative impact on the growth, development and reproductive functions of microorganisms, plants, animals and humans (Henkel, 2018). Lead, cadmium, copper, zinc are highly toxic heavy metals penetrating into soils with fertilizers, most of which are phosphoric (Gunkel-Grillon et al., 2015; Couto et al., 2016). Some of the heavy metals contained in fertilizers can enter plants and accumulate in them in significant amounts (Weissengruber et al., 2018).

World lead production has been steadily increasing and its anthropogenic levels are much higher than the natural background levels (Sutherland et al., 2000; Alsbou \& Al-Khashman, 2017). Lead is a neurotoxic substance that adversely affects the central and peripheral nervous systems, damages the digestive, urinary, cardiovascular, endocrine systems, and causes metabolic disorders. The prolonged introduction of heavy metals into the body of cows through soil, food and water causes liver disease as well as diseases of other systems of the body. This is confirmed by the high content of aspartate aminotransferase, gamma- glutamyltransferase, lactate dehydrogenase and level of urea in blood serum (Mahrelo, 2007).

The industrial emission of cadmium into the atmosphere is three times higher than its natural flow. Cadmium is classified as a microelement, which penetrates the body mainly through the gastrointestinal tract and during breathing (Hiatt \& Huff, 1975). The studies revealed (Gray, 2003) that the use of phosphate fertilizers leads to an increase in cadmium level in soil. As a consequence, the level of cadmium in cultivated plants increases. It damages the liver, kidneys, pancreas and can cause emphysema and lung cancer (Waalkes, 2000; Brzóska \& Moniuszko-Jakoniuk, 2001).

Copper, unlike cadmium and lead, is a vital component which is a component of hormones and affects the growth, development, reproduction, metabolism, hemoglobin formation, phagocytic activity of leukocytes, participates in carbohydrate and mineral metabolism and oxidative-recovery processes. Short-term contact, any treatment or use of any container made of copper material can pollute food or water ( $\mathrm{Yu}$ et al., 2000). Zinc affects the basic vital processes: hematopoiesis, reproduction, growth and development of the body, metabolism of proteins, fats and carbohydrates, oxidation-reduction reactions, energy metabolism, the processes of milk production, and has an impact on myocardial regeneration and its response to acute stress in the heart (Korichneva, 2006).

Nitrates are compounds of nitrogen that are naturally synthesized in the environment due to reactions in the nitrogen cycle. Sources of introduction of nitrogen into the environment are fertilizers, animal excre- 
ment and wastewater, fossil fuel combustion. As a result, dairy products derived from cows may have an increased concentration of nitrates that enter the body with food and water (Indyk \& Woolard, 2011). The toxic effects of nitrates are hypoxia which develops as a result of impaired transport of oxygen in the blood, as well as suppression of the activity of enzyme systems involved in the processes of tissue respiration.

Radioactive elements are undeniable mutagens. The main ones that determine the radiation state are ${ }^{90} \mathrm{Sr}$ and ${ }^{137} \mathrm{Cs}$ (Omar-Nazir et al., 2018). The chemical properties of cesium and strontium radionuclides are similar to those of potassium and calcium; therefore, they are easily included in the trophic chain "soil $\rightarrow$ plants $\rightarrow$ plant production" and accumulate in food products (Gudkov, 2006). Most of the territory of Ukraine is contaminated with ${ }^{137} \mathrm{Cs}$ which emerges when uranium and plutonium decay. ${ }^{137} \mathrm{Cs}$ forms highly soluble compounds, is available to plants and accumulates in them (Burger \& Lichtscheidl, 2018). The inflow of radioactive elements and heavy metals into the human body with food is mainly due to their transition from soil to plants and then to livestock products (Sugiyama et al., 2007; Burger \& Lichtscheidl, 2018).

The ability to adapt to the effects of environmental conditions, while preserving homeostasis, is an essential property of all living organisms. Throughout life a constant adaptation to changes of these conditions occurs. On farms, animals are exposed to various factors that can cause stress: the transfer of animals from one group to another, fighting for dominance, transportation, veterinary care, living in large groups, changes in technology, the impact of harmful substances on the organism and others (Mylostyvyi \& Chernenko, 2019). Under these conditions, the organism can fall out of state of equilibrium with the environment (Moberg et al., 2000; Carroll et al., 2013), and there are some homeostasis disorders (Friend, 1980; Igono et al., 2008). Due to the individual characteristics of the organism some animals are less susceptible to daily operational loads and react in a relatively balanced manner, while others have a sharp reaction which unbalances the neuro-hormonal system and leads to the disorders in homeostasis (Lefcourt et al., 1982; Borell et al., 2007a). Researchers aimed to determine the individual adaptive abilities of animals in response to stress by measuring the dynamics of cortisol concentration in the blood before and one hour after the stress effect (Hopster et al., 1999). It was determined that the initial concentration of cortisol in the blood of cows was only 0.5 $15.0 \mathrm{ng} / \mathrm{mL}(1.4-41.4 \mathrm{nmol} / \mathrm{L})$, and after the repeat sampling of blood $4.5-22.6 \mathrm{ng} / \mathrm{mL}(12.4-62.3 \mathrm{nmol} / \mathrm{L})$. Attention was paid to the fact that the maximum concentration of cortisol in the blood occured 30 and 60 minutes after the impact of stress. Some animals resistant to stress restore homeostasis faster. They do not undergo a sharp deterioration of health, do not decrease performance and the reproduction function is not disrupted (Beilharz et al., 1982; Borell et al., 2007b). Less stress-resistant animals react to the same stress factor so severely that it causes abrupt changes in the organism (Giesecke et al., 1985; Wolfenson et al., 2000). They may have dysfunction of the udder during machine milking, decrease in milk yield and the quality of milk and shortening of the life of cows in herds, since stress is a mechanism for body deterioration (Wenzel et al., 2003; Heikkilä et al., 2012). At the same time, no evidence is availible on how disorder of homeostasis and general stress resistance affect the ability of the body of cows to remove harmful substances with milk, although the safety of the milk depends on it. The study of local bovine animals represents a scientific novelty. Their ability to excrete harmful substances with milk due to stress is still a problem that needs to be solved. However, this issue is relevant since industrial pollution of the environment in Ukraine is increasing. In particular, a lot of industrial plants which are the source of contamination are concentrated in Dnipropetrovsk region: an unmodernized thermal power plant, a car battery manufacturing plant, the Piatykhatky ore mining complex, and in Taromske village near Dnipro city radioactive wastes are stored. In addition, the Zaporizhzhya Nuclear Power Plant is located within $100 \mathrm{~km}$ of Dnipro city. This study emphasises that differences in adaptive ability of the organism are caused by the development of a genetically determined type of higher nervous activity and this influences the possibility of increasing the dairy cattle stress resistance in a selective way. The objective of this study was to establish a relationship between the different adaptive potentials of Ukrainian black-and-white milk breeding cows with the ability of their organism to excrete via milk heavy metal salts, nitrates and radioactive elements ingested with food and water.

\section{Materials and methods}

The experimental part of the research was carried out in accordance with the requirements of European Convention for the Protection of Vertebrate Animals used for Experimental and other Scientific Purposes (Strasbourg, 1986). The resistance of cows to stress was determined by the concentration of cortisol in the blood one hour after the stress effect (Hopster et al., 1999). The following factors were stressful: fixation of animals for one hour and pre-selection of blood for general analysis. Blood samples were taken by a veterinary surgeon, from the left jugular vein. Blood was taken in the morning before feeding the animals. Immediately after labeling, each test tube was placed in a container with ice, in which it was transported to the laboratory of "VIS-Medik" plc (Ukraine, Dnipro). Cows were divided into groups with high, medium and low resistance to stress, respectively, with the deviation: the first group was less than $\mathrm{x}-\mathrm{SD}$, the second was from $\mathrm{x}-\mathrm{SD}$ to $\mathrm{x}+\mathrm{SD}$, the third group was more than $\mathrm{x}+\mathrm{SD}$. The concentration of cortisol on average was $158.9 \mathrm{nmol} / \mathrm{L}$ for 73 experimental cows, and a standard deviation of $54.3 \mathrm{nmol} / \mathrm{L}$. Experimental cows $(\mathrm{n}=73)$ had cortisol concentrations in blood serum after stress in the range $20-283 \mathrm{nmol} / \mathrm{L}$. Cows with a high resistance to stress had (I group, $\mathrm{n}=11$ ) the concentration equaling $20-100$, cows of the middle group had the concentration (II, $\mathrm{n}=51$ ) 106-213 and the concentration in the cows with low stress resistance (group III, $\mathrm{n}=11$ ) was 219-283 nmol/L (Fig. 1).

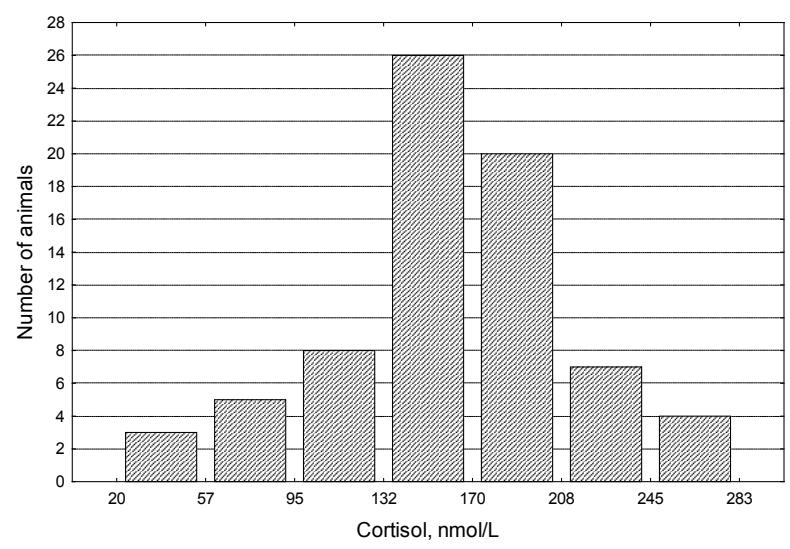

Fig. 1. Cortisol distribution frequency one hour after stress effect: $\mathrm{n}=73 ; \mathrm{x}=161 ; \mathrm{SD}=52 ; \max =283 ; \min =20$

To determine the level of cortisol, test kits of the company Alkor-Bio (Russia) and IFA reader Labline 022 Labline company (Austria) were used. The method is based on the competition between the unlabeled antigen and the enzyme-labeled antigen for a certain number of antibody bonds. The number of enzyme-labeled antigens bound to the antibodies is inversely proportional to the concentration of the unlabeled antigens. The dairy productivity of the cows was taken into account (Table 1).

Table 1

Milk productivity of cows for the first lactation $(\mathrm{x} \pm \mathrm{SD})$

\begin{tabular}{cccc}
\hline \multirow{2}{*}{ Features } & \multicolumn{3}{c}{ Groups of animals } \\
\cline { 2 - 4 } & $\mathrm{I}, \mathrm{n}=11$ & $\mathrm{II}, \mathrm{n}=51$ & $\mathrm{III}, \mathrm{n}=11$ \\
\hline Annual yield for 305 days, $\mathrm{kg}$ & $5286 \pm 395^{\mathrm{a}}$ & $4619 \pm 462^{\mathrm{b}}$ & $4110 \pm 353^{\mathrm{c}}$ \\
Content in milk: fat, \% & $3.66 \pm 0.09^{\mathrm{a}}$ & $3.62 \pm 0.24^{\mathrm{a}}$ & $3.61 \pm 0.32^{\mathrm{a}}$ \\
protein, $\%$ & $3.18 \pm 0.08^{\mathrm{a}}$ & $3.09 \pm 0.16^{\mathrm{a}}$ & $3.06 \pm 0.14^{\mathrm{a}}$ \\
\hline
\end{tabular}

Note: different letters indicate values which reliably differed from another within the table according to the Bonferroni correction.

The data presented in Table 1 indicate that the content of fat and protein in the milk of the animal groups differed little. However, milk yields were higher by $1176 \mathrm{~kg}\left(\mathrm{~F}=54.2, \mathrm{~F}_{0.0166}=4.35 ; \mathrm{P}=4.1 \cdot 10^{-7}\right)$ in cows of the first group, by $509 \mathrm{~kg}\left(\mathrm{~F}=11.8, \mathrm{~F}_{0.0166}=4.00 ; \mathrm{P}=1.1 \cdot 10^{-3}\right)$ in cows of the second groups, compared with the one year old cows of the third group. 
A chemical, toxicological and radiological analysis of fodders, water and milk from highly resistant, medium and low-stressed groups of cows was carried out depending on the seasons of the year in Dnipro Regional State Laboratory of Veterinary Medicine.

The salts of heavy metals were determined on a spectrophotometer Helios Delta, Thermo Elektron company (USA).

Nitrates were determined in milk and fodder on the ionometer Cyber Scan Ion 510 Eutech company (Netherlands). The content of the radioactive elements, ${ }^{137} \mathrm{Cs}$ and ${ }^{90} \mathrm{Sr}$, was measured using universal spectrometric complex Gamma plus Exim company (Ukraine).

The number of harmful substances which penetrated the organism during the year was determined by calculation, based on their content in the seasonal fodders in diets per day. The amount of fodder consumed per day (in $\mathrm{kg}$ ) was multiplied by the number of harmful substances in $1 \mathrm{~kg}$ of this fodder; the result was multiplied by the duration of the corresponding season of the year. According to the general consumption of harmful substances, their total amount which got into the body with fodder was determined. Similar calculations were made with water based on its consumption at the rate of $65 \mathrm{~L}$ per day.

Over the year, the substances which entered the organism of cows in the largest amounts with water and fodder were nitrates, zinc and copper (Table 2).

\section{Table 2}

Total amount of harmful substances which entered the organism of cows with fodder and water (per animal in a year)

\begin{tabular}{lccc}
\hline \multirow{2}{*}{ Indexes } & \multicolumn{2}{c}{ Harmful substances entered } & \multirow{2}{*}{ Total, g } \\
\cline { 2 - 3 } & with water, mg & with fodder, mg & \\
\hline Lead & 128.11 & 1457.73 & 1.59 \\
Cadmium & 16.63 & 440.24 & 0.46 \\
Copper & 6999 & 144379 & 151 \\
Zinc & 2444 & 339141 & 342 \\
Nitrates & 355875 & 5867301 & 6223 \\
\hline
\end{tabular}

Analysis of the data was performed using Statistica 6.0 (StatSoft Inc., USA) program. The data are presented in tables as $\mathrm{x} \pm \mathrm{SD}(\mathrm{x} \pm$ standard deviation). Differences between the groups were determined using the Tukey test, where the differences were consi-dered reliable at $\mathrm{P}<0.05$ (taking into account the Bonferroni correction).

\section{Results}

The largest amount of lead in milk of experimental cows was in summer. In particular, the cows of the first group had lower content of lead in comparison with the third group by $3 \mu \mathrm{g} / \mathrm{kg}\left(\mathrm{F}=45.00, \mathrm{~F}_{0.0166}=\right.$ $\left.4.35 ; \mathrm{P}=1.6 \cdot 10^{-6}\right)$ in the spring and $2 \mu \mathrm{g} / \mathrm{kg}\left(\mathrm{F}=13.8, \mathrm{~F}_{0.0166}=4.35\right.$; $\left.\mathrm{P}=1.3 \cdot 10^{-3}\right)$ in winter. Cows of the second group took an intermediate position.

\section{Table 3}

The content of lead $(\mu \mathrm{g} / \mathrm{kg})$ in milk of cows with different reactions to stress $(\mathrm{x} \pm \mathrm{SD}, \mathrm{n}=11$, duration of experiment -365 days $)$

\begin{tabular}{lccc}
\hline \multirow{2}{*}{ Seasons } & \multicolumn{3}{c}{ Groups of animals } \\
\cline { 2 - 4 } & I & II & III \\
\hline Spring & $10.1 \pm 1.2^{\mathrm{a}}$ & $11.7 \pm 0.8^{\mathrm{b}}$ & $13.1 \pm 1.1^{\mathrm{c}}$ \\
Summer & $41.2 \pm 4.3^{\mathrm{a}}$ & $42.4 \pm 3.7^{\mathrm{a}}$ & $45.2 \pm 4.9^{\mathrm{a}}$ \\
Autumn & $13.6 \pm 1.8^{\mathrm{a}}$ & $14.1 \pm 1.6^{\mathrm{a}}$ & $15.2 \pm 1.9^{\mathrm{a}}$ \\
Winter & $14.1 \pm 1.2^{\mathrm{a}}$ & $14.6 \pm 1.4^{\mathrm{ab}}$ & $16.1 \pm 1.4^{\mathrm{b}}$ \\
\hline
\end{tabular}

Note: see Table 1.

\section{Table 4}

The content of cadmium $(\mu \mathrm{g} / \mathrm{kg})$ in milk of cows with different reactions to stress $(\mathrm{x} \pm \mathrm{SD}, \mathrm{n}=11$, duration of experiment -365 days)

\begin{tabular}{lccc}
\hline \multirow{2}{*}{ Seasons } & \multicolumn{3}{c}{ Groups of animals } \\
\cline { 2 - 4 } & I & II & III \\
\hline Spring & $1.21 \pm 0.42^{\mathrm{a}}$ & $1.53 \pm 0.51^{\mathrm{a}}$ & $3.12 \pm 1.12^{\mathrm{b}}$ \\
Summer & $2.42 \pm 0.53^{\mathrm{a}}$ & $2.11 \pm 0.64^{\mathrm{a}}$ & $2.34 \pm 0.71^{\mathrm{a}}$ \\
Autumn & $1.84 \pm 0.44^{\mathrm{a}}$ & $2.51 \pm 0.32^{\mathrm{a}}$ & $2.45 \pm 0.52^{\mathrm{a}}$ \\
Winter & $1.91 \pm 0.52^{\mathrm{a}}$ & $2.12 \pm 0.44^{\mathrm{ab}}$ & $3.11 \pm 0.61^{\mathrm{b}}$ \\
\hline
\end{tabular}

Note: see Table 1.
The content of cadmium in milk of cows by season of the year differed depending on their reaction to stress, except for the summer, when there was a stable level of it with no changes. Cows of the first and second groups had the lowest amount of cadmium in spring and the third group - in summer. In the third group of cows, the milk content of this element was the largest, compared with the first group, by $1.91 \mu \mathrm{g} / \mathrm{kg}\left(\mathrm{F}=31.2, \mathrm{~F}_{0.0166}=4.35 ; \mathrm{P}=1.8 \cdot 10^{-5}\right)$ in spring and $1.20 \mu \mathrm{g} / \mathrm{kg}\left(\mathrm{F}=27.3, \mathrm{~F}_{0.0166}=4.34 ; \mathrm{P}=4.1 \cdot 10^{-5}\right)$ in winter. The cows of the second group took an intermediate position.

\section{Table 5}

The content of copper $(\mu \mathrm{g} / \mathrm{kg})$ in the milk of cows with different reactions to stress $(x \pm S D, n=11$, duration of experiment -365 days $)$

\begin{tabular}{lccc}
\hline \multirow{2}{*}{ Seasons } & \multicolumn{3}{c}{ Groups of animals } \\
\cline { 2 - 4 } \multicolumn{1}{c}{ I } & II & III \\
\hline Spring & $296 \pm 29^{\mathrm{a}}$ & $309 \pm 28^{\mathrm{a}}$ & $325 \pm 32^{\mathrm{a}}$ \\
Summer & $267 \pm 20^{\mathrm{a}}$ & $269 \pm 16^{\mathrm{a}}$ & $283 \pm 29^{\mathrm{a}}$ \\
Autumn & $323 \pm 39^{\mathrm{a}}$ & $330 \pm 38^{\mathrm{a}}$ & $331 \pm 41^{\mathrm{a}}$ \\
Winter & $291 \pm 27^{\mathrm{a}}$ & $292 \pm 29^{\mathrm{a}}$ & $297 \pm 34^{\mathrm{a}}$ \\
\hline
\end{tabular}

Note: see Table 1.

The lowest level of copper in the milk of animals of all groups was observed in summer, the highest in autumn. Regardless of the season, the content of copper was stably higher in the third group of cows. The difference between the first and the third groups was $29 \mu \mathrm{g} / \mathrm{kg}$ in spring, $16 \mu \mathrm{g} / \mathrm{kg}$ in summer, $8 \mu \mathrm{g} / \mathrm{kg}$ in autumn and $6 \mu \mathrm{g} / \mathrm{kg}$ in winter (the result is unreliable). The cows of the second group took an intermediate position.

\section{Table 6}

The content of zinc $(\mu \mathrm{g} / \mathrm{kg})$ in the milk of cows with different reactions to stress ( $\mathrm{x} \pm \mathrm{SD}, \mathrm{n}=11$, duration of experiment -365 days)

\begin{tabular}{lccc}
\hline \multirow{2}{*}{ Seasons } & \multicolumn{3}{c}{ Groups of animals } \\
\cline { 2 - 4 } & I & II & III \\
\hline Spring & $848 \pm 83^{\mathrm{a}}$ & $940 \pm 72^{\mathrm{b}}$ & $1032 \pm 77^{\mathrm{c}}$ \\
Summer & $1511 \pm 101^{\mathrm{a}}$ & $1512 \pm 96^{\mathrm{a}}$ & $1521 \pm 92^{\mathrm{a}}$ \\
Autumn & $1842 \pm 245^{\mathrm{a}}$ & $1890 \pm 143^{\mathrm{a}}$ & $1898 \pm 265^{\mathrm{a}}$ \\
Winter & $1010 \pm 41^{\mathrm{a}}$ & $1016 \pm 58^{\mathrm{a}}$ & $1032 \pm 112^{\mathrm{a}}$ \\
\hline
\end{tabular}

Note: see Table 1.

The content of zinc also varied depending on the season. In all groups, its lowest level was observed in spring, the highest in autumn. In all seasons the lowest level of zinc was in milk of cows of the first group. The largest differences were observed in the spring when the difference between the first and the third group was $-184 \mu \mathrm{g} / \mathrm{kg}(\mathrm{F}=$ $\left.29.1, \mathrm{~F}_{0.0166}=4.35 ; \mathrm{P}=2.8 \cdot 10^{-5}\right)$, and between the first and the second group $-92 \mu \mathrm{g} / \mathrm{kg}\left(\mathrm{F}=7.6, \mathrm{~F}_{0.0166}=4.35 ; \mathrm{P}=1.2 \cdot 10^{-2}\right)$ while the third and the second group differed by $92 \mu \mathrm{g} / \mathrm{kg}\left(\mathrm{F}=8.5, \mathrm{~F}_{0.0166}=4.35 ; \mathrm{P}=\right.$ $\left.8.6 \cdot 10^{-3}\right)$.

\section{Table 7}

The content of nitrates $(\mu \mathrm{g} / \mathrm{kg})$ in the milk of cows with different reactions to stress ( $x \pm \mathrm{SD}, \mathrm{n}=11$, duration of experiment -365 days)

\begin{tabular}{lccc}
\hline \multirow{2}{*}{ Seasons } & \multicolumn{3}{c}{ Groups of animals } \\
\cline { 2 - 4 } & I & II & III \\
\hline Spring & $419 \pm 29^{\mathrm{a}}$ & $446 \pm 28^{\mathrm{a}}$ & $506 \pm 28^{\mathrm{b}}$ \\
Summer & $1696 \pm 135^{\mathrm{a}}$ & $1999 \pm 178^{\mathrm{b}}$ & $2305 \pm 189^{\mathrm{c}}$ \\
Autumn & $1238 \pm 156^{\mathrm{a}}$ & $1473 \pm 110^{\mathrm{b}}$ & $1749 \pm 106^{\mathrm{c}}$ \\
Winter & $496 \pm 43^{\mathrm{a}}$ & $556 \pm 55^{\mathrm{b}}$ & $631 \pm 48^{\mathrm{c}}$ \\
\hline
\end{tabular}

Note: see Table 1.

Increase in the content of nitrates was observed in summer and autumn in animals of all groups. However, a dependence of nitrate content on cows' stress resistance group was revealed. In particular, the difference between the first and third groups was $87 \mu \mathrm{g} / \mathrm{kg}\left(\mathrm{F}=51.9, \mathrm{~F}_{0.0166}=\right.$ 4.35; $\left.\mathrm{P}=5.6 \cdot 10^{-7}\right)$ in spring, $609 \mu \mathrm{g} / \mathrm{kg}\left(\mathrm{F}=75.5, \mathrm{~F}_{0.0166}=4.35 ; \mathrm{P}=\right.$ $\left.3.2 \cdot 10^{-8}\right)$ in summer, $511 \mu \mathrm{g} / \mathrm{kg}\left(\mathrm{F}=81.7, \mathrm{~F}_{0.0166}=4.35 ; \mathrm{P}=1.7 \cdot 10^{-8}\right)$ in autumn, $135 \mu \mathrm{g} / \mathrm{kg}\left(\mathrm{F}=48.8, \mathrm{~F}_{0.0166}=4.35 ; \mathrm{P}=8.9 \cdot 10^{-7}\right)$ in winter. The cows of the second group took an intermediate position.

In addition to these elements, the specific activity of cesium and strontium in the milk of cows of different groups was determined. 
Table 8

Specific activity of cesium $(\mathrm{Bq} / \mathrm{kg})$ in milk of cows with different reactions to stress $(x \pm S D, n=11$, duration of experiment -365 days $)$

\begin{tabular}{lccc}
\hline \multirow{2}{*}{ Seasons } & \multicolumn{3}{c}{ Groups of animals } \\
\cline { 2 - 4 } \multicolumn{1}{c}{ I } & II & III \\
\hline Spring & $3.24 \pm 0.13^{\mathrm{a}}$ & $3.61 \pm 0.15^{\mathrm{b}}$ & $3.91 \pm 0.21^{\mathrm{c}}$ \\
Summer & $3.51 \pm 0.18^{\mathrm{a}}$ & $3.68 \pm 0.31^{\mathrm{ab}}$ & $3.92 \pm 0.14^{\mathrm{b}}$ \\
Autumn & $2.95 \pm 0.19^{\mathrm{a}}$ & $3.47 \pm 0.25^{\mathrm{b}}$ & $3.91 \pm 0.35^{\mathrm{b}}$ \\
Winter & $5.89 \pm 0.16^{\mathrm{a}}$ & $5.92 \pm 0.17^{\mathrm{a}}$ & $6.11 \pm 0.24^{\mathrm{a}}$ \\
\hline
\end{tabular}

Note: see Table 1.

Specific activity of cesium in the milk of cows varies depending on the season. The lowest specific activity was observed in autumn, and the highest in winter. In particular, the difference between the first and third groups was $0.67 \mathrm{~Bq} / \mathrm{kg}\left(\mathrm{F}=30.7, \mathrm{~F}_{0.0166}=4.35 ; \mathrm{P}=2.1 \cdot 10^{-5}\right)$ in spring, $0.41 \mathrm{~Bq} / \mathrm{kg}\left(\mathrm{F}=16.6, \mathrm{~F}_{0.0166}=4.35 ; \mathrm{P}=5.8 \cdot 10^{-4}\right)$ in summer and $0.96 \mathrm{~Bq} / \mathrm{kg}\left(\mathrm{F}=62.7, \mathrm{~F}_{0.0166}=4.35 ; \mathrm{P}=1.4 \cdot 10^{-7}\right)$ in autumn. The cows of the second group took an intermediate position.

\section{Table 9}

Specific activity of strontium $(\mathrm{Bq} / \mathrm{kg})$ in milk of cows with different reactions to stress $(\mathrm{x} \pm \mathrm{SD}, \mathrm{n}=11$, duration of experiment -365 days)

\begin{tabular}{lccc}
\hline \multirow{2}{*}{ Seasons } & \multicolumn{3}{c}{ Groups of animals } \\
\cline { 2 - 4 } \multicolumn{1}{c}{ I } & II & III \\
\hline Spring & $2.53 \pm 0.19^{\mathrm{a}}$ & $2.69 \pm 0.15^{\mathrm{a}}$ & $2.98 \pm 0.17^{\mathrm{b}}$ \\
Summer & $2.33 \pm 0.21^{\mathrm{a}}$ & $2.61 \pm 0.18^{\mathrm{a}}$ & $2.95 \pm 0.23^{\mathrm{b}}$ \\
Autumn & $2.04 \pm 0.14^{\mathrm{a}}$ & $2.38 \pm 0.13^{\mathrm{b}}$ & $2.91 \pm 0.17^{\mathrm{c}}$ \\
Winter & $2.81 \pm 0.31^{\mathrm{a}}$ & $2.84 \pm 0.21^{\mathrm{a}}$ & $2.86 \pm 0.27^{\mathrm{a}}$ \\
\hline
\end{tabular}

Note: see Table 1.

Compared to the animals of the third group, the lowest specific activity of strontium differed by $0.45 \mathrm{~Bq} / \mathrm{kg}\left(\mathrm{F}=12.9, \mathrm{~F}_{0.0166}=4.35 ; \mathrm{P}=\right.$ $1.8 \cdot 10^{-3}$ ) in milk of cows of the first group in spring, by $0.62 \mathrm{~Bq} / \mathrm{kg}$ $\left(\mathrm{F}=23.9, \mathrm{~F}_{0.0166}=4.35 ; \mathrm{P}=9.1 \cdot 10^{-5}\right)$ in summer, by $0.87 \mathrm{~Bq} / \mathrm{kg}(\mathrm{F}=$ $\left.89.1, \mathrm{~F}_{0.0166}=4.35 ; \mathrm{P}=8.2 \cdot 10^{-9}\right)$ in autumn. The cows of the second group took an intermediate position.

\section{Discussion}

Over the past 30 years, scientists have been actively studying the influence of heavy metals on the environment, health of animals and humans (Duxbury, 1985; Ali et al., 2013). Very few positive changes have occurred in the environmental conditions of Ukraine. Therefore, the study of the safety of cow's milk is of particular relevance (Boyko et al., 2016). Pollution of the environment occurs due to atmospheric emissions of enterprises (Hiatt \& Huff, 1975; Chaney et al., 2000), waste from livestock farms and the use of mineral fertilizers and pesticides on agricultural land. With the use of organic materials, the concentration in the soil of such chemical elements as lead, cadmium, copper, zinc, iron, manganese increases (Dudka et al., 1996), and therefore the risk of them entering into the body of both animals and humans increases. Heavy metals are a group of microelements, i.e. metals and metaloids with a greater atomic density than $4 \pm 1 \mathrm{~g} / \mathrm{cm}^{3}$, for example $\mathrm{Cu}, \mathrm{Zn}, \mathrm{Hg}, \mathrm{Cd}$, $\mathrm{Pb}, \mathrm{Sn}, \mathrm{Fe}, \mathrm{Mn}, \mathrm{Ag}, \mathrm{Cr}, \mathrm{Co}, \mathrm{Ni}, \mathrm{As}, \mathrm{Al}$ and others. The ions of these metals are considered to be the most common toxic mineral pollutants of soil and water systems (Mohammed et al., 2011). Microelements in soils may be in water-soluble form, available to plants. Carbonates, oxides and organic compounds are less available. The ratio of these fractions, as well as the acidity of the soil, depends on the intensity of accumulation of microelements in the plant tissues and, subsequently, in organisms of animals and humans (Bennett et al., 2003; Angle \& Linacre, 2005). Lead is the most dangerous among heavy metals, which negatively affects the metabolic processes of the body. It enters the environment from the casting manufacturing, combustion of industrial waste, coal, oil, melting and processing of non-ferrous metals or from exhaust gases of motor vehicles. Cadmium is a heavy metal that is widespread in various ecosystems, including soils and ore, where it is associated with zinc. It is present in low concentrations (Shirai et al., 1993). It becomes introduced into the environment from volcanic eruptions and by release from plants (Williams \& Harrison, 1984). Cadmium is a muta- gen, a carcinogen, a potential genetic hazard, cumulative, highly toxic in the organisms of animals and humans and blocks the functioning of enzymes vital for the organism. Copper is widely used in various sectors of the economy, including rural areas. Zinc, similarly to copper, is a microelement that is vital for the growth and development of any organism. It is present in all the organs and tissues of animals. The level of nitrates requires constant control, since they have a wide range of toxic effects, affecting the body at different biological levels. The hypoxic state can mostly occur in such tissues of the body, where an intense cell division is taking place (Kabariya \& Ramani, 2018). Accumulation of harmful substances in the soil-plant system affects a number of soil properties (Wong, 2003). For example, with growing acidity of the soil, their mobility in its layers and the introduction of ${ }^{90} \mathrm{Sr} i{ }^{137} \mathrm{Cs}$ into plants increase (Howard et al., 2017, Abraham et al., 2018). According to the Institute of Agriculture of Polissya National Academy of Sciences of Ukraine, among the studied grain crops, oats accumulated ${ }^{137} \mathrm{Cs}$ most of all, winter wheat, spring barley and finally winter rye accumulated the least amount of ${ }^{137} \mathrm{Cs}$ (Deisan et al., 2009). Leguminous cultures with high calcium content accumulate more strontium compared to cereals (Dubchak, 2017).

Research has revealed evidence that variations in adaptive capability of cows affect their ability to excrete harmful substances with milk. The source of introduction of lead, cadmium, copper, zinc, nitrates, cesium, and strontium into the organism of animals is food and water (Dubchak, 2017; Abraham et al., 2018). Then these substances enter the bloodstream. More productive cows naturally consume more water and feed and have a higher conversion rate. There is no special mechanism in the body for the excretion of these substances except for urine, and lactating animals can excrete them with milk. Research has demonstrated that stress under the influence of adrenaline increases arterial pressure (Friend, 1980). This provides more intense filtration of these substances from the blood vessels. Because of this, the kidneys of animals which are more sensitive to stress may excrete more harmful substances with urine, as well as with milk. The difference in the excretion of these substances in cows of different groups with urine was not investigated. However, milk productivity was investigated and it was found that milk yields were dramatically different. Cows with higher resistance to stress had higher milk yields. They can excrete more lead, cadmium, copper, zinc, nitrates, cesium and strontium in absolute quantities with milk. However, when daily milk yields are higher the concentration of these substances per $1.0 \mathrm{~L}$ of milk may be less in comparison with animals with lower level of milk yields.

The seasonal fluctuations in the content of harmful substances in the milk of cows of different groups are explained by the same fact. In summer, when the weather is extremely hot, experimental cows are put out to pasture and grazed on meadows without sheds. Animals do not have the opportunity to shelter from the sun under the canopies, because they are not even provided by construction projects. After all, earlier, there was no problem of sunburn, except in the South of the country. This can cause stress (Bernabucci et al., 2014; Schüller et al., 2014). The results of the research on this issue in the same agricultural firm have already been published (Chernenko et al., 2018). As a consequence, a decrease in milk yeild can occur due to the deterioration of feed consumption among all animals, but to a greater extent among cows with low resistance to stress (Hammami et al., 2015; Sailo et al., 2017). After all, in summer, temperature indicators in Ukraine have increased by $2-3$ degrees over the recent years alone (Martazynova et al., 2016). In autumn the conditions for keeping cows are different. They return from summer pasture to confined premises. Regrouping and adaptation to the altered technological conditions can also lead to a decrease in milk yield, particularly in low stress-resistant animals, especially in cows after first calving (Gorewit et al., 1992; Wenzel et al., 2003). In cows calving occurs mainly in winter. In the first three to four months of lactation, cows produce the highest amount of milk. However, milk production among cows with high resistance to stress in this period is much higher than among cows with low resistance to stress. Consequently, the data obtained do not contradict the hypothesis that different adaptive abilities may be also related to different concentrations of harmful substances per $1.0 \mathrm{~L}$ of milk. Further future research 
may include the influence of stress resistance of cows on the suitability of milk to be used in production of baby food products.

\section{Conclusions}

Out of the studied elements introduced into the organisms of cows with water and fodder during a year, those found in the highest concentrations were nitrates, zinc and copper. The concentrations of lead, cadmium, zinc and nitrates was lower in the milk of cows from the first group. It had the lowest specific activity of ${ }^{137} \mathrm{Cs}$ and ${ }^{90} \mathrm{Sr}$. Reliable results for all seasons were obtained only for nitrates and for ${ }^{137} \mathrm{Cs}$ and ${ }^{90} \mathrm{Sr}$ - in spring, summer and autumn. The milk of cows with higher stress resistance was safer in terms of the the content of these components. The data obtained do not contradict the hypothesis that cows with different adaptive abilities may excrete harmful substances with milk at different levels. Therefore, it is advisable to breed dairy herds from animals that are more resistant to stress.

\section{References}

Abraham, J., Meusburger, K., Waldis, J. K., Ketterer, M. E., \& Zehringer, M. (2018). Fate of ${ }^{137} \mathrm{Cs},{ }^{90} \mathrm{Sr}$ and ${ }^{239+240} \mathrm{Pu}$ in soil profiles at a water recharge site in Basel, Switzerland. Journal of Environmental Radioactivity, 182, 85-94.

Ali, H., Khan, E., \& Sajad, M. A. (2013). Phytoremediation of heavy metals concepts and applications. Chemosphere, 91 (7), 869-881.

Alsbou, E. M. E., \& Al-Khashman, O. A. (2017). Heavy metal concentrations in roadside soil and street dust from Petra region, Jordan. Environmental Monitoring and Assessment, 190(1), 93-102.

Angle, J. S., \& Linacre, N. A. (2005). Metal phytoextraction - a survey of potential risks. International Journal of Phytoremediation, 7(3), 241-254.

Kabariya, R. B., \& Ramani, V. M. (2018). Chromogenic method for the instant detection of adulterants in milk. International Journal of Current Microbiology and Applied Sciences, 7(4), 467-472.

Beilharz, R. G., \& Zeeb, K. (1982). Social dominance in dairy cattle. Applied Animal Ethology, 8, 79-97.

Bennett, L. E., Burkhead, J. L., Hale, K. L., Terry, N., Pilon, M., \& Pilon-Smits, E. A. H (2003). Analysis of transgenic Indian mustard plants for phytoremediation of metal-contaminated mine tailings. Journal of Environment Quality, 32(2), 432.

Bernabucci, U., Biffani, S., Buggiotti, L., Vitali, A., Lacetera, N., \& Nardone, A. (2014). The effects of heat stress in Italian Holstein dairy cattle. Journal of Dairy Science, 97(1), 471-486.

Borell, E., Dobson, H., \& Prunier, A. (2007a). Stress, behaviour and reproductive performance in female cattle and pigs. Hormones and Behavior, 52(1), 130-138.

Borell, E., Langbein, J., Després, G., \& Hansen, S. (2007b). Heart rate variability as a measure of autonomic regulation of cardiac activity for assessing stress and welfare in farm animals - a review. Physiology and Behavior, 92(3), 293-316.

Boyko, O. O., Zazharska, N. M., \& Brygadyrenko, V. V. (2016). The influence of the extent of infestation by helminths upon changes in body weight of sheep in Ukraine. Visnyk of Dnipropetrovsk University. Biology, Ecology, 24(1), 3-7.

Brzóska, M., \& Moniuszko-Jakoniuk, J. (2001). Interactions between cadmium and zinc in the organism. Food and Chemical Toxicology, 39(10), 967-980.

Burger, A., \& Lichtscheidl, I. (2018). Strontium in the environment: Review about reactions of plants towards stable and radioactive strontium isotopes. Science of the Total Environment, 653, 1458-1512.

Carroll, J. A., \& Forsberg, N. E. (2013). Influence of stress and nutrition on cattle immunity. Veterinary Clinics of North America: Food Animal Practice, 23(1), $105-149$.

Chaney, R., Brown, S., Malik, M., Siebielec, G., Kukier, U., Ryan, J., \& Scott Angle, J. (2001). Heavy metal aspects of compost use. In: Stoffella, P. J., \& Kahn, B. A. (Eds.). Compost utilization in horticultural cropping systems. Lewis Publishers, Boca Raton, London, New York, Washington. Pp. 327-363.

Chernenko, O. M., Chernenko, O. I., Shulzhenko, N. M., \& Bordunova, O. G. (2018). Biological features of cows with different levels of stress resistance. Ukrainian Journal of Ecology, 8(1), 466-474.

Couto, R. R., Lazzari, C. J. R., Trapp, T., De Conti, L., Comin, J. J., Martins, S. R. Belli Filho, P., \& Brunetto, G. (2016). Accumulation of copper and zinc fractions in soil following the application of pig slurry for three to thirty years in a microwatershed of southern Brazil. Archives of Agronomy and Soil Science, 62, 593-616.

Deisan, M. M., Didkivskyi, M. P., \& Dankevych, Y. M. (2009). Kompleksna prohrama rozvytku silskoho hospodarstva Zhytomyrskoi oblasti u 2009$2010 \mathrm{rr}$. ta na period do $2015 \mathrm{r}$ [Comprehensive program of agricultural development in Zhytomyr region in 2009-2010 and for the period up to 2015]. Ruta, Zhytomyr (in Ukrainian).
Dubchak, S. (2017). Distribution of strontium in soil: Interception, weathering, speciation, and translocation to plants. In: Gupta, D., \& Walther, C. (Eds.). Behaviour of strontium in plants and the environment. Springer International Publishing, New York. Pp. 33-43.

Dudka, S., Ponce-Hernandez, R., Tate, G., \& Hutchinson, T. C. (1996). Forms of $\mathrm{Cu}, \mathrm{Ni}$, and $\mathrm{Zn}$ in soils of Sudbury, Ontario and the metal concentrations in plants. Water, Air, and Soil Pollution, 90, 531-542.

Duxbury, T. (1985). Ecological aspects of heavy metal responses in microorganisms. In: Marshall, K. C. (Ed.). Advances in Microbial Ecology. Springer, Boston. Vol. 8. Pp. 185-235.

Friend, T. H. (1980). Stress: What is it and how can it be quantified. International Journal for the Study of Animal Problems, 1(6), 366-374.

Giesecke, W. H., \& Bigalke, R. D. (1985). The effect of stress on udder health of dairy cows. Onderstepoort Journal of Veterinary Research, 52, 175-193.

Gorewit, R. C., Svennersten, K., Butler, W. R., \& Uvnas-Moberg, K. (1992). Endocrine responses in cows milked by hand and machine. Journal of Dairy Science, 75(2), 443-448.

Gray, C. W., McLaren, R. G., \& Roberts, A. H. C. (2003). Cadmium leaching from some New Zealand pasture soils. European Journal of Soil Science, 54(1), 159-166.

Gudkov, I. N. (2006). Strategy of biological radiation protection of biota at the radionuclide contaminated territories. In: Cigna, A. A., \& Durante, M. (Eds.). Radiation risk estimates in normal and emergency situations. NATO security through science series. Springer, Dordrecht. Pp. 101-108.

Gunkel-Grillon, P., Roth, E., Laporte-Magoni, C., \& Le Mestre, M. (2015). Effects of long term raw pig slurry inputs on nutrient and metal contamination of tropical volcanogenic soils, Uvéa Island (South Pacific). Science of the Total Environment, 533, 339-346.

Hammami, H., Vandenplas, J., Vanrobays, M.-L., Rekik, B., Bastin, C., \& Gengler, N. (2015). Genetic analysis of heat stress effects on yield traits, udder health, and fatty acids of Walloon Holstein cows. Journal of Dairy Science, 98, 4956-4968.

Heikkilä, A.-M., Nousiainen, J. I., \& Pyörälä, S. (2012). Costs of clinical mastitis with special reference to premature culling. Journal of Dairy Science, 95, 139-150.

Henkel, R. (2018). Environmental contamination and testicular function. In: Suresh Sikka, C., \& Hellstrom, W. J. G. (Eds.). Bioenvironmental issues affecting men's reproductive and sexual health. Academic Press, New Orleans. Pp. 191-208.

Hiatt, V., \& Huff, J. E. (1975). The environmental impact of cadmium: An overview. International Journal of Environmental Studies, 7(4), 277-285.

Hopster, H., van der Werf, J. T. N., Erkens, J. H. F., \& Blokhuis, H. J. (1999). Effects of repeated jugular puncture on plasma cortisol concentrations in loose-housed dairy cows. Journal of Animal Science, 77(3), 708-714.

Howard, B. J., Wells, C., Barnett, C. L., \& Howard, D. C. (2017). Improving the quantity, quality and transparency of data used to derive radionuclide transfer parameters for animal products. 2. Cow milk. Journal of Environmental Radioactivity, 167, 254-268.

Igono, M. O., \& Johnson, H. D. (2008). Physiologic stress index of lactating dairy cows based on diurnal pattern of rectal temperature. Journal of Interdisiplinary Cycle Research, 21(4), 303-320.

Indyk, H. E., \& Woollard, D. C. (2011). Contaminants of milk and dairy products: nitrates and nitrites as contaminants. In: Fuquay, J. W., Fox, P. F., \& McSweeney, P. L. H. (Eds.). Encyclopedia of dairy sciences, Second Edition. Academic Press, San Diego. Pp. 906-911.

Korichneva, I. (2006). Zinc dynamics in the myocardial redox signaling network. Antioxidants and Redox Signaling, 8, 1707-1721.

Kumar, R., Singh, R. K., Kumar, V., \& Moshkalev, S. A. (2019). Functionalized nanosize graphene and its derivatives for removal of contaminations and water treatment. In: Naushad, M. (Ed.). A new generation material graphene: Applications in water technology. Springer Cham. Pp. 133-185.

Lefcourt, A. M., \& Akers, R. M. (1982). Endocrine responses of cows subjected to controlled voltages during milking. Journal of Dairy Science, 65(11), 2125-2130.

Mahrelo, N. V. (2007). Vplyv tekhnohennoho navantazhennia seredovyshcha na orhanizm koriv [Influence of technogenic loading of the environment on the body of cows]. Zbirnyk Naukovykh Prats Luhanskoho Natsionalnoho Ahrarnoho Universytetu, Seriia "Veterynarni Nauky", 78, 382-385 (in Ukrainian).

Martazynova, V. F., Ivanova, E. K., \& Scheglov, A. A. (2016).Tendentsiya sovremennogo temperaturno-vlazhnostnogo rezhima Ukrainy $\mathrm{k}$ anomalnosti zaschet atmosfernyih protsessov $\mathrm{v}$ letniy sezon [The tendency of the modern temperature and humidity regime of Ukraine to abnormalities due to atmospheric processes in the summer season]. Naukovi Pratsi Ukrayinskoho NaukovoDoslidnoho Hidrometeorolohichnoho Instytutu, 268, 15-24 (in Ukrainian).

Moberg, G. P., \& Mench, J. A. (2000). The biology of animal stress: Basic principles and implications for animal. University of California, CABI Publishing, New York. Pp. 111-118.

Mohammed, A. S., Kapri, A., \& Goel, R. (2011). Biomanagement of metal-contaminated soils. In: Khan, M., Zaidi, A., Goel, R., \& Musarrat, J. (Eds.). Heavy metal pollution: Source, impact, and remedies. Springer, Dordrecht. Pp. 1-28.

Mylostyvyi, R., \& Chernenko, O. (2019). Correlations between environmental factors and milk production of Holstein cows. Data, 4(3), 103. 
Omar-Nazir, L., Shi, X., Moller, A., Mousseau, T., Byun, S., Hancock, S., \& Mothersill, C. (2018). Long-term effects of ionizing radiation after the Chemobyl accident: Possible contribution of historic dose. Environmental Research, 165, 55-62.

Sailo, L., Gupta, I. D., Das, R., \& Chaudhari, M. V. (2017). Physiological response to thermal stress in Sahiwal and Karan Fries cows. International Journal of Livestock Research, 7(5), 275-283.

Schüller, L. K., Burfeind, O., \& Heuwieser, W. (2014). Impact of heat stress on conception rate of dairy cows in the moderate climate considering different temperature-humidity index thresholds, periods relative to breeding, and heat load indices. Theriogenology, 81(8), 1050-1057.

Shirai, T., Iwasaki, S., Masui, T., Mori, T., Kato, T., \& Ito, N. (1993). Enhancing effect of cadmium on rat ventral prostate carcinogenesis induced by 3,2 '-dimethyl-4 aminobiphenyl. Japanese Joumal of Cancer Research, 84(10), 1023-1030.

Sikdar, S., \& Kundu, M. (2017). A review on detection and abatement of heavy metals. ChemBioEng Reviews, 5(1), 18-29.

Sugiyama, H., Terada, H., Takahashi, M., Iijima, I., \& Isomura, K. (2007). Contents and daily intakes of gamma-ray emitting nuclides, ${ }^{90} \mathrm{Sr}$, and ${ }^{238} \mathrm{U}$ using marketbasket studies in Japan. Joumal of Health Science, 53(1), 107-118.

Sutherland, R. A., Tack, F. M. G., Tolosa, C. A., \& Verloo, M. G. (2000). Operationally defined metal fractions in road deposited sediment, Honolulu, Hawaii. Journal of Environment Quality, 29(5), 1431.
Vasilenko, I. Y. (1999). Radioaktivnyiy tseziy-137 [Radiative cesium-137]. Priroda, 3, 70-76 (in Ukrainian).

Waalkes, M. P. (2000). Cadmium carcinogenesis in review. Journal of Inorganic Biochemistry, 79, 241-244.

Weissengruber, L., Möller, K., Puschenreiter, M., \& Friedel, J. K. (2018). Long-term soil accumulation of potentially toxic elements and selected organic pollutants through application of recycled phosphorus fertilizers for organic farming conditions. Nutrient Cycling in Agroecosystems, 110(3), 427-449.

Wenzel, C., Schönreiter-Fischer, S., \& Unshelm, J. (2003). Studies on step-kick behavior and stress of cows during milking in an automatic milking system. Livestock Production Science, 83, 237-246.

Williams, C. R., \& Harrison, R. M. (1984). Cadmium in the atmosphere. Experientia, 40(1), 29-36.

Wolfenson, D., Roth, Z., \& Meidan, R. (2000). Impaired reproduction in heatstressed cattle: Basic and applied aspects. Animal Reproduction Science, 60(2), 535-547.

Wong, M. (2003). Ecological restoration of mine degraded soils, with emphasis on metal contaminated soils. Chemosphere, 50(6), 775-780.

Yu, B., Zhang, Y., Shukla, A., Shukla, S. S., \& Dorris, K. L. (2000). The removal of heavy metal from aqueous solutions by sawdust adsorption - removal of copper. Journal of Hazardous Materials, 80, 33-42. 